\title{
Detection of heartworm antigen without cross-reactivity to helminths and protozoa following heat treatment of canine serum
}

\author{
Jeff M. Gruntmeir ${ }^{1}$, Nina M. Thompson ${ }^{1}$, Maureen T. Long ${ }^{1}$, Byron L. Blagburn² and Heather D. S. Walden ${ }^{{ }^{*}}$ (i)
}

\begin{abstract}
Background: Detection of Dirofilaria immitis, or heartworm, through antigen in sera is the primary means of diagnosing infections in dogs. In recent years, the practice of heat-treating serum prior to antigen testing has demonstrated improved detection of heartworm infection. While the practice of heat-treating serum has resulted in earlier detection and improved sensitivity for heartworm infections, it has been suggested that heat treatment may cause cross reactivity with $A$. reconditum and intestinal helminth infections of dogs. No studies have assessed the potential cross-reactivity of these parasites with heartworm tests before and after heat treatment using blood products and an appropriate gold standard reference.
\end{abstract}

Methods: Canine sera $(n=163)$ was used to evaluate a heartworm antigen-ELISA (DiroCHEK ${ }^{\circledR}$ ) and potential crossreactivity with common parasitic infections. The heartworm status and additional parasite infections were confirmed by necropsy and adult helminth species verified morphologically or by PCR, and feces evaluated by centrifugal fecal flotation.

Results: Intestinal parasites were confirmed in 140 of the dogs by necropsy, and 130 by fecal flotation. Acanthocheilonema reconditum microfilariae were confirmed in 22 dogs. Prevalence of heartworm infection confirmed by necropsy was 35.6\% (58/163). In the 105 dogs without heartworms, specificity remained unchanged at 100\% both before and after heat treatment despite confirmed infections with A. reconditum, Ancylostoma caninum, Ancylostoma brasiliense, Trichuris vulpis, Toxocara canis, Dipylidium caninum, Spirometra mansonoides, Macracanthorynchus ingens, Cystoisospora sp., Giardia sp., and Sarcocystis sp.

Conclusions: These findings suggest that the use of heat treatment improves sensitivity of heartworm tests and is unlikely to cause false positive antigen results due to Acanthocheilonema reconditum, intestinal helminths, and protozoal parasites in dogs.

Keywords: Dirofilaria immitis, Acanthocheilonema reconditum, Heat treatment, Intestinal parasites, Microfilariae, Cross reactivity, Antigen

\footnotetext{
*Correspondence: hdstockdale@ufl.edu

${ }^{1}$ Department of Comparative, Diagnostic and Population Medicine, University of Florida College of Veterinary Medicine, 1945 SW 16th Avenue, Gainesville, FL 32610, USA

Full list of author information is available at the end of the article
}

\section{Background}

The use of antigen testing to aid in the diagnosis of canine heartworm infections has been a vital tool for veterinarians since 1985. Commercialized antigen tests, primarily based on monoclonal antibodies generated from adult

(c) The Author(s) 2021. This article is licensed under a Creative Commons Attribution 4.0 International License, which permits use, sharing, adaptation, distribution and reproduction in any medium or format, as long as you give appropriate credit to the original author(s) and the source, provide a link to the Creative Commons licence, and indicate if changes were made. The images or other third party material in this article are included in the article's Creative Commons licence, unless indicated otherwise in a credit line to the material. If material is not included in the article's Creative Commons licence and your intended use is not permitted by statutory regulation or exceeds the permitted use, you will need to obtain permission directly from the copyright holder. To view a copy of this licence, visit http://creativeco mmons.org/licenses/by/4.0/. The Creative Commons Public Domain Dedication waiver (http://creativecommons.org/publicdomain/ zero/1.0/) applies to the data made available in this article, unless otherwise stated in a credit line to the data. 
heartworm antigen preparations following acid and heat purification [1], or other identified non-cross-reactive antigens [2], demonstrated high specificity [3-5]. The relative high specificity of commercial Dirofilaria immitis antigen tests is in contrast to the cross-reactive nature of antibody tests historically used for $D$. immitis $[6,7]$ and more recently described as a diagnostic approach examining human exposure to Dirofilaria sp. [8, 9] and potential application for $D$. repens infected dogs [10].

Prior to 1995, manufacturer protocols for many commercial heartworm antigen tests used chemical and/or low heat $\left(60-70 C^{\circ}\right)$ immune complex dissociation (ICD) steps. However recently heat ICD treatment of serum at an elevated temperature of $104 \mathrm{C}^{\circ}$ has been shown to allow earlier detection and improved sensitivity for $D$. immitis antigen [3]. No decrease in specificity has been observed in pathogen free dogs when using this elevated heating step or an acid ICD prior to antigen testing [3, 11]. Heat ICD is also unlikely to cause false positive results on heartworm tests in dogs infected by $O$. lupi [13].

Studies evaluating commercial antigen test specificity have used blood products from dogs experimentally or naturally infected with Acanthocheilonema reconditum, Dirofilaria repens, Onchocerca lupi, Toxocara canis, Ancylostoma caninum, Ancylostoma brasiliense, Uncinaria stenocephala, Trichuris vulpis, Dipylidium caninum, Strongyloides stercoralis, Spirocerca lupi and Angiostrongylus vasorum [1, 4, 6, 12-19, 21]. In most instances, no cross reactivity with antigen tests was observed using serum from dogs both with or without the historical ICD steps [1, 4, 6, 12-16, 19], however two commercially available tests were shown to cross-react with A. vasorum [17], and three demonstrated crossreactivity with $S$. lupi [18]. In a rare case, an exceptionally high infection intensity by Acanthocheilonema dracunculoides, induced a false antigen positive result using normal manufacturer protocols [20]. Dirofilaria repens has recently been confirmed to cross-react with 3 heartworm tests following heat ICD in a small number of experimentally infected $n=3$ dogs [21]. Although some but not all cases of naturally infected, patent $D$. repens infections, have positive antigen results post-heat ICD [22].

Several recent publications have added confusion to the literature by stating Acanthocheilonema reconditum causes false positives with heartworm tests [23-27] misciting a study using a non-commercialized ELISA based antibody test [7], or based on interpretation of study results using an inappropriate gold standard reference (PCR results) [26], which can neither verify nor rule out an occult (amicrofilaremic) D. immitis infection or D. repens infection. Additionally, conclusions of studies using non-biologically relevant samples, such as saline soakings of intestinal helminths, to assess cross-reactivity with heartworm tests, are potentially misleading [23]. Currently no published studies suggesting cross reactivity of $A$. reconditum or intestinal helminths with heartworm antigen tests, with or without heat ICD of naturally sourced canine serum, have ruled out occult $D$. immitis infection by necropsy.

In this study, using sera from 163 dogs, 100 of which were previously characterized based on heartworm composition (adults and microfilariae) and antigen results with and without heat ICD [28], we assessed heartworm antigen detection in relation to potential cross-reactivity with $A$. reconditum, intestinal helminths and protozoan infections using a commercially available heartworm antigen test.

\section{Methods}

From 2017 to 2020, 163 previously euthanized dogs were collected and necropsied at the University of Florida College of Veterinary Medicine. All dogs collected during this time period were included in this study. The abdominal and thoracic cavities were thoroughly inspected for parasites prior to and following removal of the heart, lungs, caudal esophagus, thoracic aorta, and gastrointestinal (GI) tract. The entire GI tract was opened and mucosa scraped and rinsed into a $355 \mu \mathrm{m}$ sieve for parasite recovery. Helminths were rinsed in phosphate buffered saline (PBS) and stored in 70\% ethanol. Feces removed from the colon was examined by centrifugal flotation using Sheather's sugar (SG 1.26), and when necessary, by acid fast staining (i.e. Cryptosporidium verification) [29]. Antigen testing was completed using the DiroCHEK ${ }^{\circledR}$ assay (Zoetis LLC, Parsippany, NJ) both before and after heat ICD of serum [3]. Heat ICD was performed with a reduced starting serum volume of $400 \mu \mathrm{l}[28]$.

Whole blood from all dogs was examined for microfilariae by direct smear and Modified Knott's technique (MKT). Microfilariae recovered from whole blood by MKT were identified morphometrically [3, 29, 30]. Microfilariae from whole blood samples were processed for DNA extraction (DNeasy Blood and Tissue kit, Qiagen) [31], modified by using elution buffer heated to $70{ }^{\circ} \mathrm{C}$. Microfilariae species were confirmed by conventional PCR, specific for D. immitis (12S rDNA) and D. repens (12S $\mathrm{rDNA}$ ), using single-plex reactions to increase sensitivity [32]. Specific PCR for A. reconditum (cox1) was performed as described [31] modified by using $54{ }^{\circ} \mathrm{C}$ as the optimal annealing temperature. A Filariid-generic PCR assay targeting cox1 and $12 \mathrm{~S}$ rDNA genes were also used for mono-infections [31]. 
The prevalence (PR), sensitivity (SE), specificity (SP), negative (NPV) and positive predictive values (PPV), and 95\% confidence intervals ("exact" Clopper-Pearson) were calculated for antigen results using a diagnostic test $2 \times 2$ contingency table using a commercial statistical software (MedCalc Statistical Software version 19.1.2). The McNemar paired $\chi^{2}$ test was used to compare SE and SP before and after heat treatment of serum and for the calculation of two sided $p$-values, with $P<0.05$ considered statistically significant [33]. The PPV, the probability that the disease is present when the test is positive, was calculated as $\mathrm{SE} \times \mathrm{PR} /[\mathrm{SE} \times \mathrm{PR}+(1-\mathrm{SP}) \times(1-\mathrm{PR})]$. The NPV, the probability that the disease is absent when the test is negative, was calculated as $\mathrm{SP} \times(1-\mathrm{PR}) /[(1-\mathrm{SE}) \times \mathrm{PR}$ $+\mathrm{SP} \times(1-\mathrm{PR})][34]$.

\section{Results}

The presence of $D$. immitis adult or immature adult worms was verified by necropsy. Viable heartworms were found in 58/163 (35.6\%) dogs (Table 1). Of those, 51/58 had mature heartworms present (36 mixed sex, 8 female only, 7 male only). Ectopic infections were present in 4 of the $58 \mathrm{D}$. immitis necropsy positive dogs, each with a single live mature heartworm in the thoracic cavity. Only 3 of these 4 dogs with ectopic $D$. immitis also had heartworms recovered from the cardiopulmonary system, 1 of the 4 had only the single $D$. immitis in the thoracic cavity. Additionally, 7/58 had only immature heartworms (3 female and 4 male only). A total of 105 dogs, without viable heartworms present at necropsy, were classified as non-infected. Microfilariae were detected in 38/163 blood samples by the MKT (Table 1); 30/58 heartworm infected dogs and 8/105 heartworm non-infected dogs. A total of $48.3 \%$ of heartworm infected dogs had occult infections. Of the $30 \mathrm{MKT}$ positive heartworm infected dogs, 15 blood samples had microfilariae morphologically identified as $D$. immitis only, 1 sample with $D$. immitis and two microfilariae of an unknown species (measuring $427 \times 7.6 \mu \mathrm{m}$ and $408.6 \times 7.3 \mu \mathrm{m}$ ), 2 samples had microfilariae of $A$. reconditum only, and 12 with microfilariae of both $D$. immitis and $A$. reconditum. Microfilariae of all $8 \mathrm{MKT}$ positive samples in heartworm non-infected dogs were identified as $A$. reconditum (Table 1 ). Molecular confirmation of microfilariae (Table 1) included D. immitis specific PCR targeting $12 \mathrm{~S}$ rDNA and amplified all 28 MKT positive samples for $D$. immitis microfilariae. $A$ reconditum specific PCR targeting cox1, amplified all 10 MKT positive samples where $A$. reconditum was the only microfilariae detected. The $A$. reconditum cox 1 PCR did not amplify any of the 12 samples positive for $A$. reconditum when $D$. immitis was also present. Dirofilaria repens was not detected in any samples by MKT or specific $12 \mathrm{~S}$ rDNA PCR.

The sensitivity of the DiroCHEK ${ }^{\circledR}$ before and after heat treatment of sera for D. immitis antigen among all heartworm infections (Table 1) was 69.0\% (40/58) (95\% CI 55.5-80.5\%) and 87.9\% (51/58) (95\% CI 76.7-95.0\%) respectively $p=0.001$, and mature heartworms was 78.4\% (40/51) (95\% CI 64.7-88.7\%) and 98.0\% (50/51) (95\% CI 89.6-99.9\%) $\mathrm{p}=0.002$. The observed increases in sensitivity were statistically significant. Altogether, $90.9 \%$ of heartworm infected dogs initially testing false antigen negative but post-heat ICD antigen positive were verified as occult, male or female only heartworm

Table 1 Necropsy, Modified Knott's technique, DiroCHEK ${ }^{\circledR}$ antigen results with and without heat ICD, sensitivity or specificity, and PCR results for 58 Dirofilaria immitis necropsy positive and 105 D. immitis necropsy negative dogs

\begin{tabular}{|c|c|c|c|c|c|c|}
\hline D. immitis Necropsy & $\begin{array}{l}\text { Modified } \\
\text { Knott's technique } \\
\text { (\# pos) }\end{array}$ & $\begin{array}{l}\text { DiroCHEK }{ }^{\circledR}: \\
\text { antigen without } \\
\text { heat ICD } \\
\text { (\#pos/total) }\end{array}$ & $\begin{array}{l}\text { DiroCHEK }{ }^{\circledR} \text { : } \\
\text { sensitivity or } \\
\text { specificity without } \\
\text { heat ICD }\end{array}$ & $\begin{array}{l}\text { DiroCHEK }{ }^{\circledR} \text { : antigen } \\
\text { with heat-ICD (\#pos/ } \\
\text { total) }\end{array}$ & $\begin{array}{l}\text { DiroCHEK }{ }^{\circledR} \text { : } \\
\text { sensitivity or } \\
\text { specificity with heat } \\
\text { ICD }\end{array}$ & $P C R$ \\
\hline \multirow{5}{*}{$\begin{array}{l}\text { D. immitis Positive }{ }^{a, b} \\
n=58\end{array}$} & D. immitis (15) & $15 / 15$ & \multirow{5}{*}{$\begin{array}{l}\text { Sensitivity \# 69.0\% } \\
(40 / 58)\end{array}$} & $15 / 15$ & \multirow{5}{*}{$\begin{array}{l}\text { Sensitivity \# 87.9\% } \\
\quad(51 / 58)\end{array}$} & D. immitis \\
\hline & $\begin{array}{l}\text { D. immitis }+A \text {. } \\
\text { reconditum (12) }\end{array}$ & $11 / 12$ & & $12 / 12$ & & $\begin{array}{l}\text { D. immitis + } \\
\text { ND }\end{array}$ \\
\hline & $\begin{array}{l}\text { D. immitis + unk. } \\
\text { species }^{\mathrm{d}}(1)\end{array}$ & $1 / 1$ & & $1 / 1$ & & D. immitis \\
\hline & A. reconditum (2) & $0 / 2$ & & $2 / 2$ & & A. reconditum \\
\hline & Not detected (27) & $13 / 28$ & & $21 / 28$ & & - \\
\hline \multirow{2}{*}{$\begin{array}{l}\text { D. immitis Negative } \\
\qquad n=105\end{array}$} & A. reconditum (8) & $0 / 8$ & \multirow[t]{2}{*}{ Specificity 100\% } & $0 / 8$ & \multirow[t]{2}{*}{ Specificity 100\% } & A. reconditum \\
\hline & Not detected (97) & 0/97 & & 0/97 & & - \\
\hline
\end{tabular}

\footnotetext{
a Includes 1 dog with 1 adult female heartworm present in thoracic cavity but none in pulmonary arteries

b Includes 7 dogs with only immature heartworms

c Includes 1 dog with only embolized heartworm fragments

d 2 unknown microfilariae species measuring $427.6 \times 7.6 \mu \mathrm{m}$ and $408.6 \times 7.3 \mu \mathrm{m}$
} 
infections. All 105 dogs verified as heartworm negative at necropsy tested antigen negative, a specificity of $100 \%$, (95\% CI 96.6-100.0\%) both before and after heat treatment (Table 1). Considering only mature heartworm infections, the positive predictive value of the DiroCHEK ${ }^{\circledR}$ remained unchanged at $100 \%$, and the negative predictive value improved from $85.4 \%$ (95\% CI 79.9-89.5\%) to $98.9 \%$ (95\% CI 92.9- 99.9\%) following heat treatment.

Of the 163 dogs examined in the study, intestinal helminths were recovered by necropsy in $140(85.9 \%)$ and included species of nematodes $(n=128)$, cestodes $(n=72)$, and acanthocephalans $(n=1)$. Helminths recovered by necropsy in heartworm infected dogs included A. caninum, A. brasiliense, T. vulpis, D. caninum, and Spirometra mansonoides. Helminths recovered by necropsy in heartworm non-infected dogs included $A$. caninium, $A$. brasiliense, T. vulpis, D. caninum and S. mansonoides. Additionally, GI helminths recovered only heartworm non-infected dogs were T. canis and Macracanthorynchus ingens (Table 2). The minimum, maximum, mean intensity, and standard deviation for the intestinal helminths recovered by necropsy from heartworm noninfected dogs has been summarized in Table 3, which also includes the specificity of the DiroChek ${ }^{\circledR}$ before and after heat treatment for reference. Intestinal parasite eggs detected in the feces of dogs in this study included Ancylostoma spp., Trichuris sp., Spirometra and T. canis. Additionally, oocysts of Cystoisospora sp., Sarcocystis and
Cryptosporidium sp. (only in $1 \mathrm{D}$. immitis positive dog) were found, along with Giardia cysts (Table 2).

\section{Discussion}

No cross reactivity was seen between the commercially available DiroCHEK ${ }^{\circledR}$ heartworm assay and the sera from heartworm non-infected dogs naturally infected with Acanthocheilonema reconditum, intestinal helminths and protozoan parasites in this study. The specificity was unchanged at $100 \%$ both before and after heat treatment assessed using serum from 105 confirmed heartworm non-infected dogs. Given the high level of parasitism in these heartworm non-infected dogs (Tables 1, 2, 3) this is an ideal population to assess potential cross reactivity of $A$. reconditum and intestinal parasites of variable infection intensities (Table 3). Indeed, the highest intensities of adult helminths observed among the confirmed heartworm non-infected dogs were 427, 61, and 93 for Ancylostoma caninum, Dipylidium caninum, and Trichuris vulpis respectively, none of which elicited a false positive antigen result pre- or post-ICD. Only 4 dogs had Toxocara canis, and additionally Ancylostoma brasiliense, Spirometra mansonoides and Macrocanthorynchus ingens were only found in $1 \mathrm{dog}$ each. These parasites were not detected on the heartworm antigen tests preor post-heat ICD, although only a small number of dogs with these helminths were tested. It is possible that cross reactive antigens are indeed released by $A$. reconditum or by intestinal helminths at low levels but are below

Table 2 Overall necropsy and centrifugal Sheather's sugar flotation results for gastrointestinal helminths or protozoa in 58 Dirofilaria immitis necropsy positive and 105 D. immitis necropsy negative dogs

\begin{tabular}{|c|c|c|c|c|}
\hline \multirow{2}{*}{$\begin{array}{l}\text { D. immitis necropsy } \\
\text { Gl Parasites }\end{array}$} & \multicolumn{2}{|l|}{ Positive $n=58$} & \multicolumn{2}{|c|}{ Negative $n=105$} \\
\hline & Adult worms & Flotation (eggs/cysts/oocysts) & Adult worms & ND \\
\hline \multicolumn{5}{|l|}{ Acanthocephalans } \\
\hline Macracanthorynchus ingens & ND & ND & 1 & 1 \\
\hline \multicolumn{5}{|l|}{ Cestodes } \\
\hline Dipylidium caninum & 24 & ND & 44 & ND \\
\hline Spirometra mansonoides & 3 & 1 & 1 & 19 \\
\hline \multicolumn{5}{|l|}{ Nematodes } \\
\hline Ancylostoma caninum & 42 & & 72 & \\
\hline Ancylostoma brasiliense & 1 & & 1 & \\
\hline Ancylostoma spp. & & 43 & & 83 \\
\hline Toxocara canis & ND & ND & 4 & 1 \\
\hline Trichuris vulpis & 20 & 21 & 15 & 12 \\
\hline \multicolumn{5}{|l|}{ Protozoans } \\
\hline Cryptosporidium sp. & N/A & 1 & N/A & ND \\
\hline Cystoisospora sp. & N/A & 12 & $\mathrm{~N} / \mathrm{A}$ & 19 \\
\hline Giardia sp. & N/A & ND & N/A & 1 \\
\hline Sarcocystis sp. & N/A & 1 & N/A & 1 \\
\hline
\end{tabular}

ND Not Detected, N/A Not applicable 
Table 3 Summary of the minimum, maximum, mean intensity, and standard deviation from mean of adult intestinal helminths in 105 dogs confirmed heartworm negative by necropsy, number of dogs with no helminths recovered but ova or proglottids detected, DiroCHEK ${ }^{\circledR}$ antigen results, specificity both with and without heat ICD

\begin{tabular}{|c|c|c|c|c|c|c|c|}
\hline \multirow[t]{2}{*}{ Helminth and protozoa } & \multirow[t]{2}{*}{ \# Dogs } & \multicolumn{4}{|c|}{ Gl helminths } & \multirow{2}{*}{$\begin{array}{l}\text { DiroCHEK }{ }^{\circledR}: \text { \# Dogs antigen } \\
\text { positive without heat ICD }\end{array}$} & \multirow{2}{*}{$\begin{array}{l}\text { DiroCHEK }{ }^{\circledR} \text { : \# Dogs } \\
\text { antigen positive with } \\
\text { heat ICD }\end{array}$} \\
\hline & & Min & $\operatorname{Max}$ & Mean Intensity & $\begin{array}{l}\text { St. dev. } \\
\text { from Mean }\end{array}$ & & \\
\hline Ancylostoma caninum & 72 & 1 & 427 & 44.09 & 64.09 & 0 & 0 \\
\hline Ancylostoma braziliense & 1 & 4 & 4 & 4 & 0 & 0 & 0 \\
\hline Dipylidium caninum & 37 & 1 & 61 & 7.05 & 11.54 & 0 & 0 \\
\hline Toxocara canis & 4 & 1 & 2 & 1.25 & 0.5 & 0 & 0 \\
\hline Trichuris vulpis & 15 & 1 & 93 & 9.4 & 25.8 & 0 & 0 \\
\hline Spirometra mansonoides & 1 & 2 & 2 & 2 & 0 & 0 & 0 \\
\hline Macracanthorhynchus ingens & 1 & 3 & 3 & 3 & 0 & 0 & 0 \\
\hline Ancylostoma sp. ova only & 11 & & & & & 0 & 0 \\
\hline Ancylostoma sp., T. vulpis ova only & 1 & & & & & 0 & 0 \\
\hline D. caninum: proglottids & 7 & & & & & 0 & 0 \\
\hline T. vulpis ova only & 2 & & & & & 0 & 0 \\
\hline \multirow{2}{*}{$\begin{array}{l}\text { Necropsy/flotation no parasites } \\
\text { detected }\end{array}$} & 12 & & & & & 0 & 0 \\
\hline & & & & & & Sensitivity 100\% & Sensitivity $100 \%$ \\
\hline
\end{tabular}

detectible limits. This possibility is in doubt, particularly since in this study male heartworms (6/7) were detected post heat-ICD, once thought to be undetectable due to no or low antigen released. Alternatively, if intestinal parasites do release cross reactive antigens they may be limited to the local intestinal environment, and may not enter circulation. The results of this study, in agreement with the historical literature $[1,4,6,12,14,16]$, found no evidence of cross-reactivity with these helminths, and thus if cross-reactions do occur it is likely very rarely.

The findings of this study, no observed cross-reactivity by $A$. reconditum post heat-ICD, agree with previous observations of previous studies using heat ICD in dogs where the heartworm status was unknown, only $A$. reconditum microfilariae were detected, and no antigen detected following post-heat ICD [3, 35]. Recently in a study involving shelter animals from Florida, USA, 2 dogs with only $A$. reconditum microfilariae, initially tested "no antigen detected" but converted to post-heat ICD antigen positive [36]. Though the true heartworm status was unknown, those 2 dogs likely had occult heartworm infections resulting in the post-heat ICD positive results.

The results reported in this study underscore the importance of using well-characterized samples by combining multiple diagnostic methods with necropsy to verify or rule out occult heartworm infections prior to assessing cross-reactivity of an organism with a diagnostic test. Previous studies have suggested that $A$. reconditum could cause false positive antigen results on heartworm antigen tests [23-27] by misciting an
antibody-ELISA paper [7], and others concluded this based on interpretation of Modified Knott's technique, antigen, post-heat ICD antigen results and compared with PCR as the gold standard reference [26], an inappropriate conclusion since occult heartworm infections nor $D$. repens were not ruled out by necropsy, the accepted gold standard [33]. Additionally, occult infections were proposed to be detected by Wolbachia and Filariid PCR [26], though this would require a necropsy verification of heartworm status and microfilariae testing using a filter concentration method due to its higher sensitivity versus the MKT [37]. In this study, no false positives were seen in the 8 necropsy confirmed heartworm negative dogs with $A$. reconditum identified by MKT and PCR. Another recent case report assuming cross reactivity without knowing the true heartworm status involved a previously stray dog from $D$. immitis endemic Spain, imported into the Netherlands, and suspected of heartworm infection due to microfilariae, and a post-heat ICD antigen positive test [27]. That study concluded that Acanthochilonema dracunculoides cross reacts with heartworm tests postheat ICD based primarily on the post-heat ICD antigen results, PCR results, as well as echocardiography not visualizing heartworms in the trunk or pulmonary arteries, the latter a finding not uncommon in mild asymptomatic heartworm infected dogs [27]. In that report, the postheat ICD antigen converted to "no antigen detected" approximately 3 months and 2 weeks following treatment [27]. It is possible the positive antigen results observed post-heat ICD was due to an occult $D$. immitis infection, 
known to test false negative on antigen tests, and as demonstrated in this study, $90.9 \%$ of false negative results testing positive post-heat ICD were due to male or female only occult infections. Male heartworms may also be a possible scenario for the initial post-heat ICD antigen positive results and short period ( 104 days) to "no antigen detected" post-heat ICD, particularly due to the low level of antigen released by male heartworms [38]. The observed "no antigen detected" following the 3 month two week treatment described above is similar to results of 2 owned, heartworm infected dogs (stage 1) which converted to "no antigen detected' at 89 days (post-heat ICD 130 days), and 90 days following a similar treatment regimen of doxycycline, and twice monthly imidacloprid/ moxidectin [39]. While the possibility remains that $A$. dracunculoides does indeed cross react with heartworm tests post-heat ICD, and shown to react using standard protocols under extreme infection intensities [20] at this time it should be considered inconclusive. This possibility should be further investigated with well characterized samples that are microfilaremic for A. dracunculoides, and with occult $D$. immitis and Dirofilaria repens verified absent at necropsy, or experimental samples evaluated, similar to that recently reported for D. repens [21].

While the specificity observed with the DiroCHEK ${ }^{\circledR}$ in this study was unchanged at $100 \%$ both pre-and postheat ICD antigen testing of serum, it is important to consider the animal history and clinical factors when interpreting antigen results [3]. Four of the 58 heartworm infected dogs in this study each had a single mature $D$. immitis in the thoracic cavity. One of these 4 dogs had no heartworms present in the cardiopulmonary system, only the thoracic cavity, and would have been presumably an unverifiable antigen positive by other diagnostic methods with the exception of potential eosinophilia on a CBC blood panel [39]. In another study evaluating heat-ICD of serum from necropsy confirmed samples, specificity decreased from $97.8 \%$ to 96.1 while sensitivity increased by $7.7 \%$ for mature infections [28]. In that study it was unclear if ectopic infections were present or if other factors caused the presumed false positives observed both pre-and post-heat ICD but should reinforce that no diagnostic test or method is perfect.

Given the recent reports of D. repens in a shelter dog and cat from a Florida, USA shelter and unknown whether those cases were imported or were acquired locally, there is a need for a multiple diagnostic approach and increased awareness and surveillance particularly among sheltered animals [36]. It has been recognized that imported or travel related introduction of parasites to non-endemic areas are not uncommon and suggested that veterinarians should consider non-endemic parasites as differential diagnoses [21]. Imported infections should be of increased concern given that the Centers for Disease Control and Prevention (CDC) estimates approximately 1.06 million dogs are imported into the United States each year [40].

Parasitic infections in North America known to crossreact with heartworm tests include $A$. vasorum and $S$. lupi, both rarely reported and often asymptomatic, can be diagnosed using different means and therefore, differentiated from $D$. immits $[41,42]$. In North America, $A$. vasorum is considered an emerging threat and is endemic in wild canids of Newfoundland and Nova Scotia, Canada $[41,43]$ with a single case report from a red fox from West Virginia, USA [44]. Spirocerca lupi is endemic in wild canid populations in the southeastern US and has been reported in bobcats, grey and red foxes, and coyotes in Florida, USA [45]. In this study, although methods were included to detect these parasites, they were not recovered during necropsy of dogs and D. repens was not identified by MKT or PCR testing of blood. Dracunculus insignisis, also not found in this study is suspected to cross-react with heartworm antigen tests $[3,46]$ and should be further investigated regarding potential crossreactivity with heartworm tests. Two microfilariae of an unknown species, which measured $427 \times 7.6 \mu \mathrm{m}$ and $408.6 \times 7.3 \mu \mathrm{m}$, were found during MKT with microfilariae of $D$. immitis. Since they were present in a dog with a known $D$. immitis infection, it is not determined whether or not their presence contributed to the positive heartworm antigen result.

Limitations in this study include the use of the MKT, known to have a lower sensitivity for microfilariae versus a filtration concentration method, particularly when microfilaremia is very low [37]. Although if additional microfilariae were detected among the heartworm noninfected dogs, this would only strengthen the conclusions of this study given the pre- and post-heat ICD results. Additional parasites may have been present in this population and detection aided by using fecal sedimentation or more extensive examination of additional organs and/ or soaking of the tissues. The prior history of parasite preventive in this population was unknown, although many of these dogs may have received some type of antiparasiticide prior to euthanasia, which may have reduced recovery of intestinal parasites or had an unknown effect on potential cross-reactive antigenemia.

The overall data presented here concludes that the DiroCHEK $^{\circledR}$ heartworm antigen test is unlikely to crossreact with $A$. reconditum or the intestinal parasites evaluated here with or without the use of heat ICD of serum. When evaluating potential cross reactivity of diagnostic tests, ruling out occult $D$. immitis infections, intestinal, or tissue inhabiting parasites by necropsy combined with a multiple diagnostic approach is important. Additional 
surveillance is needed for helminths in domestic dog and wild canid populations by necropsy and/or other diagnostics. Further research to determine potential crossreacting organisms is important to improve heartworm antigen tests, aid development of a definitive confirmation test, and to aid in differential diagnosis. Given the high sensitivity following heat treatment for detection of mature heartworm infections demonstrated here, and the high specificity observed in this study, the use of heat treatment may allow increased confidence for detection of mature heartworm infections in dogs without fear of compromising results due to some common, often concurrent, parasitic infections.

\section{Conclusions}

The conclusions of this study suggest that the use of heat treatment improves sensitivity of heartworm tests without false positive antigen results due to $A$. reconditum, intestinal helminths and protozoal parasites in dogs.

\section{Acknowledgements}

Not applicable

\section{Authors' contributions}

JG contributed to conceptualization, methodology, sample and data acquisition and analysis, writing and funding acquisition. NT contributed to sample and data acquisition. ML and BL contributed to conceptualization and methodology. HW contributed to conceptualization, methodology, sample and data acquisition and analysis, funding acquisition, writing and project supervision. All authors read and approved the final manuscript.

\section{Funding}

Funding received to support this research was provided in part by a joint grant from the National Center for Veterinary Parasitology and the American Heartworm Society.

\section{Availability of data and materials}

All data generated or analyzed during this study are included in the published article.

\section{Ethics approval and consent to participate}

All work was performed as approved by the University of Florida Institutional Animal Care and Use Committee protocol \#201810115.

\section{Consent for publication}

Not applicable

\section{Competing interests}

The authors declare that they have no competing interests.

\section{Author details}

${ }^{1}$ Department of Comparative, Diagnostic and Population Medicine, University of Florida College of Veterinary Medicine, 1945 SW 16th Avenue, Gainesville, FL 32610, USA. ${ }^{2}$ Department of Pathobiology, Auburn University College of Veterinary Medicine, 1130 Wire Road, Auburn, AL 36849, USA.

Received: 18 August 2020 Accepted: 29 December 2020

Published online: 22 January 2021

\section{References}

1. Weil G, Malane M, Powers K, Blair LS. Monoclonal antibodies to parasite antigens found in the serum of Dirofilaria immitis-infected dogs. J
Immun. 1985;134:1185-91. https://doi.org/10.1016/0014-4894(87)90149 -4 .

2. Ott R, Staples M, Weekley M, Maggio E. Demonstration of both immunologically unique and common antigenic determinants in Dirofilaria immitis and Toxocara canis using monoclonal antibodies. Vet Immlmmunopath. 1985;10:147-53. https://doi.org/10.1016/0165-2427(85)90042-x.

3. Little S, Saleh M, Wohltjen M, Nagamori Y. Prime detection of Dirofilaria immitis: understanding the influence of blocked antigen on heartworm test performance. Parasit Vectors. 2018;11:186. https://doi.org/10.1186/ s13071-018-2736-5.

4. Dzimianski M, McCall J. Evaluation of adult antigen diagnostic test kits using well-defined dog sera from laboratory and field trails. In: Otto G.F, editor. Proceedings of the Heartworm Symposium'86, 1986 March 21-23; New Orleans, LA, USA. Washington D.C.; American Heartworm Society: 1986. 83-86.

5. Grieve R. Advances in the immunologic diagnosis of Dirofilaria immitis infection. Sem Vet Med Surg (Sm. Anim.). 1987:4-14.

6. Thilsted JP, Whorton J, Hibbs C, Jillson G, Steece R, Stromei M. Comparison of four serotests for the detection of Dirofilaria immitis infection in dogs. Amer J Vet Res. 1987;48:837-41.

7. Gillis JM, Smith RD, Todd KS Jr. Diagnostic criteria for an enzyme-linked immunosorbent assay for occult heartworm disease: standardization of the test system in naturally exposed dogs. Amer J Vet Res. 1984;45:2289-92.

8. Simón F, Siles-Lucas M, Morchón R, González-Miguel J, Mellado I, Carretón E, et al. Human and animal dirofilariasis: the emergence of a zoonotic mosaic. ClinMicrobio Rev. 2012. https://doi.org/10.1128/CMR.00012-12.

9. Ciuca L, Simòn F, Rinaldi L, Kramer L, Genchi M, Cringoli G, et al. Seroepidemiological survey of human exposure to Dirofilaria spp. in Romania and Moldova. Acta Trop. 2018;187:169-74. https://doi.org/10.1016/j.actat ropica.2018.07.012

10. Ciuca L, Vismarra A, Lebon W, Beugnet F, Morchon R, Rinaldi L, et al. New insights into the biology, diagnosis and immune response to Dirofilaria repens in the canine host. Vet Parasit X. 2020. https://doi.org/10.1016/j. vpoa.2020.100029.

11. Starkey LA, Bowles JV, Blagburn BL. Comparison of acid- versus heattreatment for immune complex dissociation and detection of $D$. immitis antigen in canine plasma. Vet Parasit. 2020. https://doi.org/10.1016/j. vetpar.2020.109134.

12. Ely ML, Courtney CH. Sensitivity and specificity of Filarochek heartworm antigen test and Dirotect heartworm antibody test for immunodiagnosis of canine dirofilariasis. J AmerAnimHospAssoc. 1987;23:367-71.

13. De Oliveira CS, Savadelis MD, McLean NJ, Verocai GG. Assessing the potential cross-reactivity using a commercial heartworm ELISA kits of serum from dogs naturally infected with Onchocerca lupi. Vet Parasit. 2020. https://doi.org/10.1016/j.vetpar.2020.109070.

14. Brunner CJ, Hendrix CM, Blagburn BL, Hanrahan LA. Comparison of serologic tests for detection of antigen in canine heartworm infections. J Am Vet Med Assoc. 1988;192:1423-7.

15. Genchi C, Basano FS, Bandi C, Sacco BD, Venco L, Vezzoni A, et al. Factors influencing the spread of heartworms in Italy. Interaction between Dirofilaria immitis and Dirofilaria repens. In: Soll MD, Knight DH, editors. Proceedings of the Heartworm Symposium '95, 1995 March 31-April 2; Auburn, AL, USA. Batavia, III.: American Heartworm Society; 1995. 65-71.

16. McCall JW, Supakorndej N, Donoghue AR, Turnbull RK, Radecki SV. Evaluation of the performance of canine heartworm antigen test kits licensed for use by veterinarians and canine heartworm antigen tests conducted by diagnostic laboratories, and canine heartworm antigen tests conducted by diagnostic laboratories. In: Seward LE, Knight DH, editors. Recent Advances in Heartworm Disease Symposium'01. 2001 April 20-22; San Antonio, TX, USA. Batavia, III.: American Heartworm Society; 2001. 135-140.

17. Schnyder M, Deplazes P. Cross-reactions of sera from dogs infected with Angiostrongylus vasorum in commercially available Dirofilaria immitis test kits. Parasit Vectors. 2012;5:258. https://doi.org/10.1186/1756-3305-5-258.

18. Aroch I, Rojas A, Slon P, Lavy E, Segev G, Baneth G. Serological crossreactivity of three commercial in-house immunoassays for detection of Dirofilaria immitis antigens with Spirocerca lupi in dogs with benign esophageal spirocercosis. Vet Parasit. 2015;211:303-5. https://doi. org/10.1016/j.vetpar.2015.06.010. 
19. Genchi M, Mangia C, Ferrari N, Loukeri S. Evaluation of a rapid immunochromatographic test for the detection of low burden Dirofilaria immitis (heartworm) in dogs and cats. Parasit Res. 2018;117:31-4. https://doi. org/10.1007/s00436-017-5709-2.

20. Muñoz C, Gonzálvez M, Rojas A, Martínez-Carrasco C, Baneth G, Berriatua E, et al. Massive microfilaremia in a dog subclinically infected with Acanthocheilonema dracunculoides. Parasitlnt. 2020. https://doi.org/10.1016/j. parint.2020.102070.

21 Sobotyk C, Savadelis MD, Verocai GG. Detection and cross-reaction of Dirofilaria repens using a commercial heartworm antigen test kit. Vet Parasit. 2020. https://doi.org/10.1016/j.vetpar.2020.109302.

22. Ciucă L, Genchi M, Kramer L, Mangia C, Miron LD, Del Prete L, Maurelli MP, Cringoli G, Rinaldi L. Heat treatment of serum samples from stray dogs naturally exposed to Dirofilaria immitis and Dirofilaria repens in Romania. Vet Parasit. 2016;225:81-5. https://doi.org/10.1016/j.vetpar.2016.05.032.

23. Venco L, Manzocchi S, Genchi M, Kramer LH. Heat treatment and falsepositive heartworm antigen testing in ex vivo parasites and dogs naturally infected by Dirofilaria repens and Angiostrongylus vasorum. Parasit Vectors. 2017;10:476. https://doi.org/10.1186/s13071-017-2444-6.

24 Laidoudi Y, Ringot D, Watier-Grillot S, Davoust B, Mediannikov O. A cardiac and subcutaneous canine dirofilariosis outbreak in a kennel in central France. Parasite. 2019. https://doi.org/10.1051/parasite/2019073.

25 Laidoudi Y, Marié JL, Tahir D, Watier-Grillot S, Mediannikov O, Davoust B. Detection of canine vector-borne filariasis and their Wolbachia endosymbionts in French Guiana. Microorg. 2020;8:770. https://doi.org/10.3390/ microorganisms8050770.

26 Laidoudi Y, Davoust B, Varloud M, Fenollar F, Mediannikov O. Development of a multiplex qPCR-based approach for the diagnosis of Dirofilaria immitis, D. repens and Acanthocheilonema reconditum. Parasit Vectors. 2020. https://doi.org/10.1186/s13071-020-04185-0.

27. Szatmári V, van Leeuwen MW, Piek CJ, Venco L. False positive antigen test for Dirofilaria immitis after heat treatment of the blood sample in a microfilaremic dog infected with Acanthocheilonema dracunculoides. Parasit Vectors. 2020;13(1):1-6. https://doi.org/10.1186/s13071-020-04376-9.

28 Gruntmeir JM, Long MT, Blagburn BL, Walden HS. Canine heartworm and heat treatment: An evaluation using a well based enzyme-linked immunosorbent assay (ELISA) and canine sera with confirmed heartworm infection status. Vet Parasit. 2020. https://doi.org/10.1016/j.vetpa r.2020.109169.

29. Zajac AM, Conboy GA. Veterinary clinical parasitology. 8th ed. Hoboken: John Wiley \& Sons; 2012.

30. Magnis J, Lorentz S, Guardone L, Grimm F, Magi M, Naucke TJ, et al. Morphometric analyses of canine blood microfilariae isolated by the Knott's test enables Dirofilaria immitis and D. repens species-specific and Acanthocheilonema (syn. Dipetalonema) genus-specific diagnosis. Parasit Vectors. 2013;6:48. https://doi.org/10.1186/1756-3305-6-48.

31. Otranto D, Brianti E, Dantas-Torres F, Weigl S, Latrofa MS, Gaglio G, et al. Morphological and molecular data on the dermal microfilariae of a species of Cercopithifilaria from a dog in Sicily. Vet Parasit. 2011;182:221-9. https://doi.org/10.1016/j.vetpar.2011.05.043.

32. Ionică AM, Matei IA, D'Amico G, Bel LV, Dumitrache MO, Modrý D, et al. Dirofilaria immitis and $D$. repens show circadian co-periodicity in naturally co-infected dogs. Parasit Vectors. 2017;10:116. https://doi.org/10.1186/ s13071-017-2055-2.

33. Courtney $\mathrm{CH}$, Cornell JA. Evaluation of heartworm immunodiagnostic tests. J Am Vet Med Assoc. 1990;197:724-9.

34. Altman DG, Bland JM. Diagnostic tests 2: predictive values. Br Med J. 1994 https://doi.org/10.1136/bmj.309.6947.102.

35. DiGangi BA, Dworkin C, Stull JW, O'Quin J, Elser M, Marsh AE, et al. Impact of heat treatment on Dirofilaria immitis antigen detection in shelter dogs. Parasit Vectors. 2017:10:483. https://doi.org/10.1186/s13071-017-2443-7.

36. Hays KM, Rodriguez JY, Little SE, Litster AL, Mwacalimba KK, Sundstrom $\mathrm{KD}$, et al. Heartworm prevalence in dogs versus cats: Multiple diagnostic modalities provide new insights. Vet Parasit X. 2020. https://doi. org/10.1016/j.vpoa.2020.100027.

37. Altman $\mathrm{NH}$, Yarbrough B. A rapid screening program for the diagnosis of Dirofilaria immitis infections in dogs. Lab AnimSci. 1973;23:701-3.

38 Weil GJ. Dirofilariaimmitis: identification and partial characterization of parasite antigens in the serum of infected dogs. ExpParasit. 1987;64:24451. https://doi.org/10.1016/0014-4894(87)90149-4.

39. Ames MK, VanVranken P, Evans C, Atkins CE. Non-Arsenical heartworm adulticidal therapy using topical moxidectin-imidacloprid and doxycycline: a prospective case series. Vet Parasit. 2020. https://doi.org/10.1016/j. vetpar.2020.109099.

40. Pieracci EG, Pearson CM, Wallace RM, Blanton JD, Whitehouse ER, Ma $X$, et al. Vital signs: Trends in human rabies deaths and exposuresUnited States, 1938-2018. Morb Mort Wk Rep. 2019;68:524. https://doi. org/10.15585/mmwr.mm6823e1.

41. Conboy G. Canine angiostrongylosis: the French heartworm: an emerging threat in North America. Vet Parasit. 2011;176:382-9. https://doi. org/10.1016/j.vetpar.2011.01.025.

42. Rojas A, Dvir E, Baneth G. Insights on Spirocerca lupi, the carcinogenic dog nematode. Trends Parasit. 2020;36:52-63. https://doi.org/10.1016/j. pt.2019.10.004

43. Priest JM, Stewart DT, Boudreau M, Power J, Shutler D. First report of Angiostrongylus vasorum in coyotes in mainland North America. Vet Rec. 2018;183:47. https://doi.org/10.1136/vr.105097.

44. Kistler WM, Brown JD, Allison AB, Nemeth NM, Yabsley MJ. First report of Angiostrongylus vasorum and Hepatozoon from a red fox (Vulpes vulpes) from West Virginia, USA. Vet Parasit. 2014;200:216-20. https://doi. org/10.1016/j.vetpar.2013.12.007.

45. Foster GW, Main MB, Kinsella JM, Dixon LM, Terrell SP, Forrester DJ. Parasitic helminths and arthropods of coyotes (Canis latrans) from Florida, USA. Comp Parasit. 2003;70:162-6. https://doi.org/10.1654/4081.

46. Williams BM, Cleveland CA, Verocai GG, Swanepoel L, Niedringhaus $\mathrm{KD}$, Paras $\mathrm{KL}$, et al. Dracunculus infections in domestic dogs and cats in North America; an under-recognized parasite? Vet ParasitReg Stud Rep. 2018;13:148-55. https://doi.org/10.1016/j.vprsr.2018.05.005.

\section{Publisher's Note}

Springer Nature remains neutral with regard to jurisdictional claims in published maps and institutional affiliations.
Ready to submit your research? Choose BMC and benefit from:

- fast, convenient online submission

- thorough peer review by experienced researchers in your field

- rapid publication on acceptance

- support for research data, including large and complex data types

- gold Open Access which fosters wider collaboration and increased citations

- maximum visibility for your research: over 100M website views per year

At BMC, research is always in progress.

Learn more biomedcentral.com/submissions 